\title{
EARLY INDIANA PALEONTOLOGY - 1800-1860
}

\author{
CAMP, Mark J., Dept. Of Geology, University of Toledo, Toledo, OH 43606, U.S.A.
}

The first paleontologic observations in Indiana Territory most likely occurred along the Ohio River near Madison and at the Falls of the Ohio across from Louisville.

Unfortunately, little was recorded until east coast naturalists and a few geologists explored this "western" frontier. Cincinnati, Ohio; Lexington, Kentucky; and New Harmony, Indiana became centers of natural history study.

Constantine Samuel Rafinesque was one of the first to record Indiana fossils when he reported on fossil corals in the Middle Devonian limestones of the rocky flats of the Falls of the Ohio in 1820. More definitive work at this famous site began in the later 1800s.

Exploration also extended up the main tributaries of the Ohio River, including the Wabash River. William Maclure, the Father of American Geology, was the first geologist to make a home in Indiana, arriving at New Harmony in January 1826. Maclure managed to amass an impressive geologic cabinet at this remote community. As one of the founders of this Robert Owen utopian community however, non-scientific matters continued to plague him. Maclure, for health reasons, left New Harmony, for Mexico after a few years, but had planted the seeds for continuing research in natural history. Charles Alexander Lesueur, Thomas Say, and Gerard Troost, among others were attracted to the town. Although each had wide-ranging interests in natural history, each made contributions to paleontology during their careers. Maclure was also the reason that David Dale Owen, one of Robert Owen's sons, chose a career in geology in the mid-1830s.

In 1837, Owen accepted the position of Indiana State Geologist and began a survey of the geologic resources of the new state. His knowledge of paleontology is reflected in his 1837 and 1838 annual reports in which he refers to Favosites, Archimedes, Pentremites, various brachiopods, subfossil nonmarine gastropods, nautiloids, trilobites, crinoids, placoderms, and Quaternary vertebrates. In 1843, Owen traveled to Albany, N.Y. to present two papers to the Association of American Geologists and Naturalists, one on the find of rooted Pennsylvanian lycopod stumps in Posey County. In 1846, Owen helped in the study of a Devonian placoderm from Jennings County. Owen's reconnaissance of Indiana enticed many geologists to visit New Harmony, including Charles Lyell.

Another site that attracted early paleontologists was Crawfordsville. The 1932 founding of Wabash College by Rev. Edmund O. Hovey and others led to the discovery of fossiliferous zones in the Mississippian strata along Sugar Creek. As early as 1836, Hovey had assembled a sizable cabinet of fossils for the college. The discovery of well preserved intact crinoids in the 1840s and 1850s brought many collectors and paleontologists to Crawfordsville including W. H. Barris, Frank H. Bradley, Orlando W. Corey, Christian Van Deloo, and Charles Dyer.

James Hall of New York also traveled to the Hoosier state in the 1850s and later 1800s to collect from the Silurian Waldron Shale near Waldron and Hartsville and the Mississippian Salem Limestone at Harristown in Washington County. These sites were exposed due to railroad construction, the new mode of transportation in 19th century Indiana. 